\title{
Notes on 'Translatability in An Uneven World'
}

\section{R. Radhakrishnan}

\begin{abstract}
The article proposes the need to re-think modernity in order to understand modernity. Re-thinking is a reference to significant deviation from modernity. Modernity, on the other hand, is an epistemological modality of meaning and English stands as the most powerful and persuasive vehicle for the instrument of modernity. The article also emphasizes the diasporic nature of language and the loss that is concomitant with translation. Further the author equates translation with love-making and the erotic even as he expatiates on the nature of the relationship between the source language and source text on the one hand and the target language and target text on the other. The translator's love for two languages and the "purposeless purposiveness" in the translation are accounted for in the article. Finally the readerliness of the reader and the nature of an ideal reader are explained.
\end{abstract}

How does one "rethink modernity" without invoking modernity all over again in an acquiescent mode? One contingent way out perhaps is to say that the rethinking has to take the shape of a translation into a different language or into a series of languages. If modernity as colonial modernity has taken on global valence as a necessary point of departure for all future possibilities, then rethinking modernity could be seen both as a reference to and a significant deviation from modernity. When I use the term modernity I think of it as a language in two senses of the term:

Translation Today Vol. 2 No. 2 Oct. 2005 (C) CIIL 2005 
modernity as an epistemological modality of meaning, and as the dominance of English as the most powerful and persuasive vehicle and instrument of modernity. Just as one could ask, Can there be an Indian or Nigerian modernity; one could also ask a question such as: How is modernity doing in Tamil or Urdu? Particularly in the realm of culture and literature, these two registers are in perennial dialogue, since language is after all constitutive of meaning, and not a mere reflection of it. At a recent talk I gave on "Diaspora: Literature and Theory," in Tamil, one of the most interesting questions I got was: Is diaspora possible or meaningful in Tamil? The question was not about the general intelligibility of the diaspora as such, but rather about its intelligibility within the linguistic domain called Tamil. In this brief intervention I will be using the terms "translation" and "translatability" both with reference to general worldviews as well as in invocation of the representations of these realities within specific languages.

I would like to begin with a gloss on the phrase, "lost in translation". What is the mutually constitutive relationship between translation and loss? Do we even expect of a rigorous translation that it ought to foreground, avow, and thematize the loss that it has just engendered, rather than claim unimpeachable integrity and fidelity? Could we even go as far as to say that it is only when a translation is effected that the "loss" is actively constituted, i.e., we will not know what we have lost till the translation comes into play. In other words, is the active agency of the translation is a prerequisite for an affirmative valorization of our loss? But in that case, how do we distinguish between qualitative losses and shabby losses: losses occasioned by great and noble effort, and those entailed by inefficiency, inadequacy, and indifference? Since my rhetoric is tending towards the interrogative, a few more questions. What is lost as such? What is lost in life or experience? What is lost in language? What is lost in translation, within and between languages? Why can we not say, in a Borgesian way, that I am about to translate this English novel into English? I hope by now it is becoming clear that 
on the presentation to follow that is a translation of what I want to say, that I am hoping to promote an energetic interaction between translation as historical and material, and translation as "concept metaphor" in Gayatri Spivak's sense of the term. In other words, there is nothing that is not a translation, and yet, translation is a specific and delimited practice. Intelligibility without translatability would be invalid, and yet, the ethic of a good translation is to resist and problematize intelligibility. Another little gloss, by way of an episode, on the connection between intelligibility and an uneven world: Jayakanthan, an outstanding contemporary Tamil novelistshort story writer-and intellectual whose work I have translated into English, responded thus to an interlocutor who had asked Jayakanthan if he had read Sartre. "You, sir, ask me if Jayakanthan has read Sartre, whereas I ask you if Sartre has read Jayakanthan". This indeed is the fundamental unevenness that I refer to. I know that much to his benefit that Jayakanthan knows some Sartre, whereas I am quite confident that Sartre passed away without ever having been enriched by Jayakanthan. I hope you understand that I am far from criminalizing Sartre, for it was Sartre in his magnificent advocacy of Fanon who posed the question of Fanon's communicative context and his addressee: Europe or Africa. The problem is systemic and transcends the pieties of individual intentions and determinations.

Translations have something to do with love and the erotic. I would even say that a translation is an attempt to legitimate a menage a trios among the translating language, the translated language, and the act of translation. Love without erotics would be disembodied whereas a non-thematic erotics could degenerate into narcissisism. So, how does one distinguish between a loveless eroticism and an erotics of love, i.e., between love and mere infatuation? To get more specific, how does the translator's love of language emblematize itself during the act? Here are a few possibilities. The translator is in love with language or 'linguicity' as 
such and, ergo, with the two languages in question in an allegorical sort of way. ${ }^{1}$ It is an intransitive love, or a Duke Orsino kind of love that is in love with love and not with a specific person. ${ }^{2}$ In such an allegorical love, the two particular languages get transcendentally honored but historically disfigured. There is yet another problem: it cannot easily be made clear if the two languages are vehicles of the allegorical tenor in an equal or unequal way. The positioning of the translator's desire is posited in a way that does not allow for empirical or material verification.

The second scenario is what I participated in when I translated Jayakanthan and Asokamithran into English. Situated between two languages and loving both differently, I still had to be aware that the onus of intelligibility falls differently on Tamil and English, not for intrinsic philosophical reasons, but only because we live in a world structured in dominance where English is a canonically desirable world language whereas Tamil is not. A problem, or rather an ethico-aesthetic dilemma I faced, sentence after sentence, was: Should I author a resistant translation or a frictionless one? Would I have felt similarly had I been translating from English into Tamil? Though I was keen that the two masters I was translating should be relished and cherished in English by millions of people, I was equally passionate and anxious that I should not simplify the embedded magnificence of these masters. It was galling that these names were not even known in the so-called universal, cosmopolitan metropole. I wanted to be an active agent of a program whereby metropolitan readers would pay a penalty for their "sanctioned ignorance", to borrow again from Spivak. There was a feeling of resentment that the classic authors I was translating were not even heard of, for no fault of their own, and therefore, my act of translation, despite my best intensions, had to take an apologistic and or popularizing register. I would rather have the cocky, complacement metropolitan reader who would be garnering kudos for having gone out of her way to read and enjoy a translation from the third world, struggle, stumble, and even give up reading in 
dread of the "other", than exult in cheap global multiculturalism. ${ }^{3}$ My love of the space "between" took on a schizophrenic dimension. In the very act of translating well and readably, I wanted to achieve two theoretical effects: 1) the effect of a fundamental and incorrigible untranslatability to be valorized in the name of the minor languages ${ }^{4}$, and 2) the effect of alienation whereby in the act of translating Tamil into English for an English speaking reader I would create a form of English that would de-nativize the English speaking populace. The challenge then was how to achieve an organic balance between the desire to translate well and effectively and the desire to actualize a meta-translational subversion in the name of justice.

Since I have initiated the economy of desire, I may as well go with it some more and get into the adulterous erotics of translation. The translator is in love with two languages and understands that he/she is part of both linguistic formations from "within". Thus, it is not only adultery, but it is also an incestuous and/ or endogamous relationship from two directions. I find myself "between" Tamil and English only because I am already part of Tamil and part of English. To borrow from the always ubiquitously useful Edward Said, I may belong to Tamil filiatively and to English affiliatively; but in any case, I am doubly interpellated, and now I am facing a third call that stems from the between, but in honor of the two shores that account for the space of the between. So as a translator, I want to indulge myself in an affair as though it were the wedded relationship and I want the frissons of a transgressive affair as through a proper relationship. The point I want to make is that the ethics of translation as a "between job" is accountable to notions of justice without at the same time being captive to norms of the proper and the authentic. If matrimony can be thought of as an affair and an affair legitimated as matrimony within the temporality of the between, then the task of the translator has to be theorized as nonreferentially ethical, or to borrow from Kant's famous aesthetic 
"purposeless purposiveness", or better still, as ethical in an implosive or auto-telic manner. I sincerely hope that my conflation here of the ethical register with the aesthetic is quite intentional.

The task of the translator enfranchises erotic loving as a form of intransitive passion even as it gestures substantively towards possibilities of a transitive recuperation of intentional commitments and oaths of adequation and loyalty. The logic of translation has a double and reversible economy: on the one hand, it eroticizes that which is domestic and thus renders it homeless and wild, but on the other hand, it domesticates a wild and lawless passion into something like a home. To put it concretely, when I took up the task of translating Jayakanthan into English, I had to think, in some provisional way, of English as the "home" that had to be reached by Jayakanthan's Tamil, thanks to my integrity as a translator. I as translator had the double duty of honoring the radical and erotic outsiderlines of the Tamil text Vis a Vis the genius of the English language and at the same time enable the Tamil text to accept "its" English destination as valid home. And all of this had to be done without my letting English "eat the alterity" of Tamil, or allow the Tamil text to scorn or dishonor the hospitality offered by English. To put it differently, the ethic of translation dangles between erotics as an $a$ priori and the indeterminate betrayal or postponement of the $a$ priori in the living present. The only way the translator can test her love for one of the two languages is by rendering that "primary" love vulnerable to erotic siege by her love for the "secondary" language, and the only way she can be assured contingently that she is in fact in love with two languages and not with the one primarily and with the other secondarily is by loving "translation as such" passionately and purposelessly much like an architect who falls in love with a bridge without any concern about the entities that are to be connected by the bridge.

As I turn my attention inevitably towards Walter Benjamin on translation, I would like to frame the discussion a certain way. 
What does "translatability" mean in all its generality, which is to say, not the translatability of Urdu into Tagolog, or of English into Tamil, but translatability as such? Is "translatability" an existential phenomenon or a linguistic effect? When for example, an individual asserts that he or she understands a certain experience that she has had, how indeed has this experience become "available as intelligible" to the individual? Does she translate the language of experience into a specific language that in her case might be Hindi, or Arabic, or Russian? To put in Heideggerian terms, is it a translation from "the language of being" to "the being of language"? On what register is "language" inaugurated: at the ontological, or the discursive? If the very term "translatability" is part and parcel of a linguistic economy, does it then pertain to the language of being, or the being of language? In other words, does the concept metaphor ground the literal, or is it the other way around? Or to put it differently, in the context of Foucault's discussion of "verbality" in 'The Order of Things', how is the priori of language distributed between a primordial intelligibility secured as translatability, and an intelligibility of the progressive tense to be embodied in the specificity of actual translations? ${ }^{7}$

The discussion about the universality of experience despite differentiation by language has of course gone on interminably, in the context of the Tower of Babel and in the context of an ancient Sanskrit shloka that declares that though the streams be diverse they originate from the same rain and terminate in the same ocean. What is it that makes me confident that any thing at all is intelligible? Is it because it is structured like an experience that precedes diversification, differentiation, and heterogenization by language that meaning is intelligible universally, or is it because it is structured like a language that universal intelligibility is enabled? In other words, is there the need for an ontological original, or is universal intelligibility premised on the superannuation of the original and the celebration of "difference" that has no "other" or no 
"before?"8 Are the truths of translations as such as well as the truths of determinate translations to be understood as forms of radical relationality without "identical or original" recourse, or is there the strategic need, in a world structured in dominance, to invoke the "original" as a way of signaling that there is a lot of friction and static between ontology and history, between temporality and historicity? The latter strategy may well be a way also of bringing into the discussion a term that Benjamin chooses to ignore, i.e., "representation": representation as translation, and vice versa.

In Benjamin's entire discussion, it is a given that when we are talking about translation, we are talking about literary translation. In Benjamin's analysis then, literature gets both marked and unmarked as a special category. Here is how: "The Task of the Translator" begins

In the appreciation of a work of art or art form, consideration of the receiver never proves fruitful. Not only is any reference to a certain public or its representatives misleading, but even the concept of an "ideal" receiver is detrimental in the theoretical consideration of art, since all it posts is the existence and nature of man as such. Art, in the same way, points man's physical and spiritual experience, but in none of its works is it conceived with his response. No poem is intended for the reader, no picture for the beholder, no symphony for the listener ${ }^{9}$.

Benjamin achieves several critical effects here. First of all, there is the absolute valorization of a professional norm. Benjamin is a literary critic/theorist and it from within this domain of expertise he speaks and constitutes literary and or/aesthetic appreciation as the platform for discussion. What is most interesting is his negotiation with readerliness. In taking the ideal reader out of the equation, he is also disqualifying the entire category of readership and readerliness. Benjamin triangulates a relationship among "the public", "the ideal 
reader", and "theoretical considerations of art". It is obvious that Benjamin is posing himself a dilemma between democratic and elitist choices. Clearly art necessitates complex theoretical considerations that have no room for naivete either of the sociological-empiricist kind or the romanticist-idealist type. What Benjamin finds troubling and stultifying is the mere positing of "man's existence and nature as such". Clearly, he expects more of art than a smug recuperation of man's existence in terms of his ideality. A transcendence of sorts, but not one mired in the known or in a comfortable anthropocentrism. I would read his audacious claim that no art work is intended for the receiver as an invitation to a programmatic dismantling of a whole range of humanisms that wish to remain centered in their naturalized privilege. Benjamin is anticipating Foucault who in a Nietzschean vein would call for the dissolution of "the human" in the process of knowing. In not being intended for any particular terminus, the work of art releases possibilities of intransitive understanding that owe no filial allegiance to their provenance or their destination. Benjamin could also be understood as paving a way for "the aesthetic" as a secondary or "supplemental" epistemology that is not concerned with the shoring up of the human as existence or ideal nature. It is through this strategy of alienation or defamiliarization that Benjamin reconciles his anti-humanism as a form of populism. It is in art and in the theoretical considerations of art that the human recognizes itself in difference, in perennial alterity.

It might well be asked if this insistence on alienation and defamiliarization is not a case of modernist obsession. My response is that it is a modernist concern (by no means an obsession), and so what? Honestly, the modern world is the only world we have: true, each one of us, as subaltern or postcolonial or dalit or feminist subject may well signify differently on the legacy of colonial and postcolonial modernity, but even such different and adversarial or resistant significations necessarily fall within the episteme of the 
modern. I would even submit that the thesis of "translatability in an uneven world" needs to be co-articulated with notions such as transnational, contested, and alternative modernities. As a matter of fact, the coming into its own of language (what Said calls "linguicity" and what is still referred to as "the linguistic turn" in social thought) offers a great deal to theories and practices of translation as they shuttle among and between cultures. By insisting that ideas and concepts are linguistically constituted, the human subject avoids the pitfalls of an unsituated idealism, preferring instead the paths offered by synchronic and diachronic analysis of languages and their dispositions. Once we are in the realm of languages, we cannot avoid coming to terms with the Tower of Babel. Sure there are universals, but such universals are differently and relationally constituted intra-and inter-linguistically. Neither does the idea dominate the heterogeneous play of language, nor does one dominant language claim an avant-garde representative legitimacy on behalf of all other languages that supposedly follow. The leader in a way then, the task of reclaiming or rethinking modernity perspectivally becomes the function of critical negotiations, contestations, and elaborations among and within the languages of the world. The pluriform world we know speaks multilaterally, but very often it is received and understood in a uniform manner that is crafted by the dominant language. Once translation theory instills "loss" at the very heart of all languages, and moreover, insists that each language is a translation into and within itself, then, it becomes possible to appreciate and respond honestly to the heterovalences of the world and its many words. Such an understanding of the cultural politics of translation, as a matter of fact, is part of a larger thesis that argues that the colonial modern condition itself is an effect of an uneven, incomplete, and an insufficiently multilateral translation.

If colonial modernity at the height of its hubris dreamed of one world, based on "dominance without hegemony", ${ }^{10}$ then a postmodern and post-colonial condition based on the deconstructive 
truths of a world that is nothing but translation is indeed well positioned not just to read modernity against its much vaunted monolingualism, but go well beyond to imagine non binary possibilities regarding the One and the Many. It becomes possible to initially enable polylogues between deconstructive linguistic ventures and emerging linguistic endeavors (always keeping in mind the reality of an unevenness hatched in dominance that I have addressed earlier on in this essay), and eventually imagine a decentered world of relational plays and possibilities. Here is Derrida thinking two thoughts at the same time: " 1 . We only ever speak one language. 2. We never speak only one language." 11 When these two propositions are put together, a space opens up where the labors of translation as "concept metaphor" and the concrete practices of translation work within a symbiotic relationship of accountability and integrity. The one does not automatically make sense to itself just as the Many are not condemned to chronic translatability as their only precondition to meaning. Aware then of the ruse of the One in the Many and the murmuring groundswell of the Many in the One, translation as meaning may, to borrow from Ralph Ellison's magnificently double-conscious modernist conclusion of his novel 'Invisible Man', perennially speak on registers other than the ones sanctioned by the dominant discourse: those other registers where recognition and representation are in a state of constant mutual negotiation ${ }^{12}$.

I would like to conclude this brief intervention with the thought that the worldly project of finding and honoring intelligibility in all its protean shapes not be reduced to questions of mastery and instrumental opportunism. All I am saying is that as I translate, say Ambai, from Tamil into English, I should also be translating Tamil and English: each into its own relative imperfection, incompleteness, and contingency. 


\section{NOTES}

1. "Linguicity" is a term that Edward Said uses in the chapter "Abecedarium culturae" in his book Beginnings to suggest the condition of being in language.

2. I refer here to Duke Orsino in William Shakespeare's The Twelfth Night and his famous lines, "If music be the food of love".

3. For more on this, please see the chapter, "The Use and Abuse of Multiculturalism" in my book Theory in an Uneven World, Blackwell 2003.

4. See Deleuze and Guattari, Kafka: Towards a Minority Literature (University of Minnesota Press), and the Nature and Context of Minority Discourse, eds. Abdul JanMohamed and David Lloyd (Oxford University Press).

5. See Abdelkebir Khatibi, Amour bilingue.

6. I refer here to an essay by Bell Hooks, "Eating the Other" in the collection in Black Looks: Race and Representation, South End Press, 1992

7. See Michel Foucault, The Order of Things and The Birth of the Clinic.

8. For a memorable exposition of the nature of "difference", see Derrida's essay with the same title in the collection The Margins of Philosophy.

9. Walter Benjamin, "The Task of the Translator," in Illuminations.

10. For an exquisite exposition of the conduct of "dominance without hegemony," see Ranajit Guha's essay in Subaltern Studies, Vol. VI.

11. Jacques Derrida, Monolingualism of the Other, Or The Prosthesis of Origin, trans. Patrick Mensah, Stanford University Press, 1998. 
12. Ralph Ellison's Invisible Man ends with these poignant and magnificent lines: "May be on another wavelength I speak for you too." 
